\title{
The Theory and Application of Utilizing Jalāl-ad-Dīn Rumi's Spiritual and Moral Views
}

\author{
Izbullaeva Gulchehra Valerievna \\ Pedagogical Department, Bukhara State University, Bukhara, Uzbekistan \\ Email: izbullayeva@mail.ru
}

Received 13 August 2014; revised 4 September 2014; accepted 14 September 2014

Copyright (C) 2014 by author and Scientific Research Publishing Inc.

This work is licensed under the Creative Commons Attribution International License (CC BY). http://creativecommons.org/licenses/by/4.0/

c) (i) Open Access

\begin{abstract}
The article gives information about pedagogical sources of learning personality and scientific heritage of Jalāl-ad-Dīn Rumi (1207-1273), his philosophical views and role in the process of upbringing, the problem of spiritual upbringing of the person in his work "Masnaviyi ma'naviy" and theoretically substantiated information about using his vies during the process of education.
\end{abstract}

\section{Keywords}

Demand, Colloquy, Word, Question and Answer, Education, Contemplation, Perfect Personality, Spiritually-Educational Upbringing

\section{Introduction}

Having considered the basic benefits of our nation at this age of globalization consequent implementation of the road to democratic development was chosen as a strategic goal. In order to fulfill this goal, the main objective was to set as to restore national and rich spiritual heritage and universal values with the help to bring up a perfect person. Because at this age of development, it is effective to rely on the national and universal values and through them to influence spiritually and morally on a person in such a difficult work as bringing up a perfect man. They help to prevent informational attacks and various spiritual threats which come from webpage's and mass media. This will certainly lead to social and economic reinforcement of our country. The flourishing of the country depends on “... bringing up the spiritually perfect people who know their rights, who rely on their strength and capacity, who can have an individual approach to the events happening around, who can reach harmony between personal interests and the interests of the country and nation” (Karimov, 2011).

This is the reason why in the national model of preparing the personnel the stress is put on upbringing the 
perfect person who is the main object and the subject, the main user and the fulfiller of the services in educational sphere. It is underlined that it is predominant to bring up the perfect person by the state and to develop versatility in him (NATIONAL instruction of trained personnel in Republic of Uzbekistan, 1997).

\section{The Actuality of the Research}

Among the great scholars of the past Jalāl-ad-Dīn Rumi has put an accent on the words "perfection" and "spirituality". His works as "Fihi Ma Fihi" (In It What's in It), "Matnawìye Ma'naw $\vec{\imath}$ " (Spiritual Couplets), "Dīwān-e Kabìr" (Great Work), "Dīwān-e Shams-e Tabrīž̀" (The Works of Shams of Tabriz), Majāles-e Sab'a (Seven Sessions), Maktubot (The Letters) are of educational and didactic value and they attract one's attention for covering universal ideas.

Studying and using them while bringing up a perfect person and indicating its innovative forms and styles is a pressing pedagogical problem. Rumi's works reflect an objective approach to various problems, accurate planning of work, didactic requirements and recommendations to scholars, the ways of establishing the rules of education and upbringing and it is necessary to study them from pedagogical point of view.

\section{The Degree of Studiedness of the Problem}

The spiritual and moral heritage of Jalāl-ad-Dīn Rumi, especially his was studied with a great interest in the East and the West. Oriental studies of Europe opened a way to studying Rumi's scientific heritage. In the works of A. Schimmel, where she analyzes Rumi's literary activity, particularly his, it is indicated that beginning from the end of XVIII century Western Europe learned about the representatives of Eastern science owing to Rumi. The names of the scholars as J. Wallenberg, J. Hammer, J. Redhose, R. Nicholson and A. J. Orberry were given as an example. Moreover, we can cite the names of V. Durant, S. Trimingem, G. Ete, U. K. Chittik, U. Burgel, K. Huar among the Western scholars who studied Rumi.

Rumi's scholarly heritage was also studied by a number of Russian scholars together with the representatives of Sufism while they studied Sufism as a part of the Eastern studies. The translations and researches of A. Krimskiy, E. Bertels, V. V. Bartold, V. A. Jukovskiy, V. Gordlevich, F. Korsh, I. Selvinskiy, M. N. Osmanov, G. Korogli, N. Martinovich, A. Mets, I. S. Braginskiy, R. Fish, A. A. Khismatullin, O. M. Yastrebov, D. Shedrovitskiy, M. Khatkevich, I. Bugaev, N. Chistyakov, L. Tirapolskiy, S. Sechev can be a good example of it.

The studies on Rumi's literery legacy were also conducted in the Eastern countries as Pakistan, India, Iran, Turkey, Azerbaijan and Tajikistan.

Starting from the $15^{\text {th }}$ century the attitude towards Rumi's works rose to the highest extent. Such men of letters as Abdurahman Jomi, Husayn Voiz Koshifi, Sheykh Odina Muhammad Khorazmi, Mirzo Abdulkodir Bedil, Boborahim Mashrab considered Rumi as their teacher and inspired by his works they created their scientific, historical and literary works.

A short period after Uzbekistan has gained its independence many effective measures were taken in order to study Rumi's spiritual heritage and forward it to readers. It is worth telling that Rumi's works were translated from Persian into Uzbek. A. Mahkam, Sh. Shohmuhammedov, J. Kamol, U. Hamdam, M. Hasaniy are among the powerful translators who translated Rumi's works. N. Komilov, E. Ochilov, O. Usmon, H. Khomidiy, I. Hakkul, H. Boltaboev, T. Kahhor, R. Jumaev, A. Samad, A. Tilavov based Rumi’s views from philosophical and literary aspect in their scientific researches.

Much work has been done in the recent years in our republic to study Rumi's sufic, scientific and philosophical views. Having philosophically analyzed Rumi's and "Fihi Ma Fihi" the scholars as G. N. Navruzova, G. T. Kobulniyozova, N. I. Zaynobidinova indicated social and spiritual importance of the ideas related to human spiritual perfection in his views. We can include into these researches K. Tuqsanov's study on the comparative analysis of the translations of Rumi's aphorisms.

Generally speaking, there have been done many researches to study Rumi's works. But they have been conducted in the sphere of Eastern studies, Literary Criticism, Sufism studies, Philosophy and partly Psychology. As a result little attention is paid to pedagogic analysis of his views. Nevertheless in the history of Pedagogics Rumi's views are highly evaluated.

The aim of the work is to study completely the theory of using Rumi's views on spiritual and moral upbringing, to create the technology of practicing it and to provide systematization of using the works of the poet in the 
system of continuous education.

\section{Social Conditions Formed Ideas}

Jalāl-ad-Dīn Rumi's real name is mentioned as Muhammad ibn Muhammad bin Husayn al-Balkhiy. His friends appreciated him as Mavlono, at the same time he had several pen-names like "Jaloliddin", "Rumi", and "Mavlaviy". Mavlono was born in 604 of hijria, in the sixth day of Rabbiulavval (1207, September 30) in "Ummul-bilod" ("Mother of cities") which meant Balkh. His father Bahouddin Muhammad (Bahovalad) was a famous speaker of the city.

It is important to know contemporary social, cultural, scientific, political and other conditions and setting together with personage before beginning to study the life of any outstanding or ordinary person. Jalāl-ad-Dīn Rumi's life and literary activity, his social, philosophical and pedagogical thinking is closely connected with the period of Muhammad Khorazmshoh reign (1199-1221) and his fight against Chingizkhan (1161-1227) who tried to build Mongolian state, and also with that period when scientific circles in Muslim world tried to give smart evidence and comparison to clever motions of that time.

Studying Mavlono Jalāl-ad-Dīn Rumi's life and literary activity, we can mention many features that can have an impact on man's personality. The head of those features was his father Bahouddin Valad, famous statesman and scientist of his time and country. Also he was called "sultan of scientists".

It was proved by Husomiddin Chalabiy and Davlatshoh Samarqandiy-the first predictors of that time that Rumi coming into the world of Sufism was foretold by Sheikh Fariduddin Attor (1151-1221). Alisher Navai described Rumi's meeting with Attor in the following way: "on the way to Mecca in Nishopur he recieved Sheikh Fariduddin Attor's conversation. Sheikh presented him his book entitled 'Asrornoma'. He always kept that book together with himself” (Navoi, 2001). During the meeting Attor was touched by the conversation with young man and said to latter's father: "Very soon your son will give relief to hurt hearts" (Iste'lomiy, 2001). Even Attor and Rumi's meeting became a legend of long ago history, it is still considered as the spiritual closeness and meeting of two saint representatives. Rumi mentioned several times about Attor and his thinking in his works, especially, in "Matnawìye". He also gave some examples of his educating works. Rumi achieved such a great spiritual power thanks to the traditions of the century and, personal Sufistic approach. Rumi’s mentor Said Burhoniddin, who taught him reading and writing, at the end of each lesson read him Attor's stories and asked student's opinion about them (Radiy, 1986).

Mavlono Rumi's meeting with Shamsiddin Tabriziy and his studying in Tabriziy hands brought great changes in Rumi's life. “Mavlono's connection with Shams is like a fan pupil's connection with his dream” (Jalāl-ad-Dīn, 2010). Shams Tabriziy was one of the well-known sheikhs under the penname Shamsuddin. Rumi himself in one of his poems wrote the following about Tabriziy: "Attor developed my spirituality, Shams Tabriziy gave a key to world secrets" (Iste’lomiy, 2001).

Mavlono died in the $17^{\text {th }}$ of December, 1273 , on Sunday. He concluded his life saying: "I was unripe, then I ripe, and was kindle". Iranian scientist Taqiy Purnomdoriyon wrote: "At the end of the XI century Sanoiy began writing irfoniy poem which was completely formed by Attor in the XIII century, and flourished with the works of Mavlavi Rumi” (Purnomdoriyon, 2001).

Jalāl-ad-Dīn Rumi 's poetry has a great spiritual content, the spiritual ideas in them serve as self understanding and closely connect people with each other, they connect also the ways between peoples' hearts, show permanent spirituality and lead people to perfect.

\section{Methods of Teaching}

The pedagogical theory of the great thinker Jalāl-ad-dīn Rumi on this problem has two dimensional and mutually related funtions.

First of all it is spiritual purification of a person and his acquirement of the ways to develop as a perfect person (Example).

Secondly, it is displaying one's inner world while coming into contact with people around. (Talk) This is the quality peculiar to Sufi teachings i.e. it is considered to be the task of a great pedagogical and social importance as humanism, high spirituality, patriotism and industriousness. The teachings of Rumi have to do with the formation, development, perfection and the realization of the person. Because the demands of innovative educational a technologies originate from it. In the process of Rumi’s pedagogical activity three qualities become ap- 
parent. They are: loving and respecting people more than loving oneself, the ability to gain knowledge and experience and the ability to impart it to students. Rumi emphasizes that upbringing of the person must have a specific goal which means that it has to be chosen aiming at human perfection, only in this case upbringing will yield positive results in the behaviors of a student; otherwise the upbringing which does not aim at the future of the student can damage a person's development and his perfection.

In the process of education the teacher first of all draws his student to himself. He will make the student love him and becomes a good example in everything. Because it is easier to learn when a person sees a live example. The first group of teaching methods include the methods of giving the information through words and accepting it by hearing-oral methods: a story, a lecture and others.

The second group of methods include giving the academic information visually and accepting it by seeingvisual methods: descriptive methods, demonstration and others.

The third group of methods include giving the academic information by practice-practical methods are organized with the help of exercises, laboratory experiments, labour activities and others.

We can observe that the literary activity and pedagogical views of the great thinkers of the East and the representatives of Sufism are related to each of the three group of teaching methods stated above. The great scholar of the Medical science Ibn Sino mostly relies on the visual method. The founder of the "Naqshbandiyyah" order Baha-ud-Din Naqshband Bukhari relied mostly on the practical method.

The pedagogical activity of prominent man of letters Jalāl-ad-Dīn Muhammad Rūmī relies on the oral method. Rumi brings up his students by frequently having colloqies with them. In his work "Fihi Ma Fihi” (In It What's in It), Rumi states that, "The point of saying a word is to bring benefit, to influence on the soul, to change the behavior and do other good deeds". He explains the essence of the word by this statement and points up "If you want to know about the person, have a conversation with him, you will learn who he is by his words" (Jalāl-ad-Dīn, 2003).

We can observe many views on the power of the word in the literary activity of the poet: "The upside of the word is that it directs you to wishing, it inspires you... All the words, sciences, crafts and arts are favored with word... All the crafts in the world, sciences and other things take life, enjoyment and temperature from the light of the learned person" (Jalāl-ad-Dīn, 2003).

It means that with the help of a word it is possible to influence on a person, to bring him up and to study him.

The light and the charm of the well-educated and wise people are definitely in their words. Rumi realizes the essence of the word deeply and finds the way into the souls of his readers through the power of his word. The poet seriously prepares before making a speech to his students and tries to explain the essence of being a man by means of the following description:

In the process of upbringing the subjective and objective attitude is formed on the basis of colloquy. The method of colloquy helps to expand the information gained in the process of pedagogic observation, to evaluate the situation properly, to create the pedagogical conditions which enable finding the solution to the problem, to involve the capability of the experiment subjects in the process of finding solutions to the problem. One of the teaching methods in Rumi's pedagogical activity is the method of question and answer. The poet states as following about the rules of asking the student a question: "The person who asked a question must understand two aspects:

The first: I have made a mistake in what I have asked. There may be more except what I already know.

The second: There is a word and wisdom superior than this and worth learning, but I did not know about it” (Jalāl-ad-Dīn, 2003). He also writes: The knowledge in the word will be lifeless, the face of the desiring will remain as a discontentment for it, if there is no customer for it and no one discusses it, The science of perfection will loose its life (Jalāl-ad-Dīn, 2010).

The greater part of the teacher and student activity passes in the way of question and answer. Because it is impossible to express it by speaking. The ability of the student to analyze the given information in his mind and to form an idea about it depends on the teacher's ability and the way he develops this skill in the student. The product of the knowledge, its result and future are organized on the basis of discussion. Discussion and debates don't take place if there is no "customer" which means if there is no asker or answerer. Because the method of question and answer consists of the process of receiving and exchanging the information and it is organized as an answer to the question. Rumi also states: "A meaningful question is half of the knowledge".

A story about a question and answer is found in "Mațnawīye Ma'nawī". A king received three letters from one person but he did not reply to the letters. That person wrote to the king again, stating "I have written to you for 
three times, either receive it or say that you won't!" The king wrote on the back of that letter "No reply is also a reply; silence is the reply to fools". Through this story Rumi talks about a wordless form of the answer. According to him "When there are too many words, the aim is forgotten, and vanishes" and "Is there any need for the word for a person who can understand without a word?” (Jalāl-ad-Dīn, 2003).

Asking improper questions without realizing the result indicates that the person is impatient. While addressing the students the poet underlines using one's mind and patience in the process of organizing discussions.

The poet states that it is important to prevent asking questions on the abstract thing in one's imagination hurriedly and without listening to the statement till the end. Judging from the ideas above we can divide Rumi's methods of upringing into the following groups:

- Colloquy (explaining, teaching, forming a habit, practicing);

- A good example (giving an advice, apologizing, a good example, edification).

Teaching methods created by Rumi according the relationship between collective are classified as following, in conclusion we can say that mother should follow healthy life style in upbringing psychologically and spiritually well-bred man, should begin introducing external world to her child even when he is in her embryo, should make him get used to external world. Mother's kindness and father's strictness are very important in family's positive development. Spiritual-aesthetic upbringing spent by mentor in the collective has a great influence on man's individual independent thinking, respect in the collective.

It is necessary to make a good use Rumi's methods of upbringing in the process of spiritual and moral development of an individual. The main aspect of Rumi's literary legacy is that it it wholly coincides the meaning of "case study" and problematic teaching technologies that are used in the present day educational process. "Case study" is the method of analyzing and solving teaching technologies. Problematic teaching is a teaching method that encourages the process of active acquirement of knowledge and forms the method of logical sequence. The essence of these education technologies is that the participants will be asked to reflect on the lifelike situations and on the account of this situation not only a practical problem, but also the academic material which must be studied in the process of solving a problem are expressed. According to these methods the learners are given a piece from lifelike situation or literature, culture, science, art and together with it some theoretical aspect is also offered. As a result of discussions and debates the problem is solved.

\section{Elements Influencing on Man's Spiritual and Aesthetic Upbringing}

There we can classify Jalāl-ad-Dīn Rumi’s great spiritual-aesthetic heritage and principles of educational process in the following way:

- social aspect of upbringing;

- connection of upbringing with life and labour;

- relay on positive features of upbringing;

- to humanize upbringing;

- sample, model in upbringing;

- personal approach.

Common, features of upbringing influence and etc. From theoretical point of view Rumi's teaching is based on "I was immature, then I am riped and full of enthusiasm", that's to say these all express "yesterday-todaytomorrow". Using all his predecessors heritage in his ideas and thoughts he said about the choise of today's activity and by understanding of it to put a foundation stone for upbringing of future generation. If we put ideas and thoughts expressed in Rumi's teaching in one line according their meaning, there appears special book of aesthetics of perfect man and by his education he divides elements influencing man's spiritual-aesthetic upbringing into four periods: mother’s embryo, family, mentor and collective.

\section{Conclusion}

Jalāl-Ad-Dīn Rumi's poetry has a great spiritual content, the spiritual ideas in them serve as self understanding and closely connect people with each other; they also connect the ways between peoples' hearts, show permanent spirituality and lead people to perfect.

As a conclusion, it is important to note that Rumi has left his precious ideas to the future generation aiming at the human benefits, future and perfection. The studies of his rich pedagogical legacy show that Rumi created a complete system of pedagogical and didactic methods which consists of the problems of a human and his up- 
bringing, the aims and problems of upbringing. And Rumi became a great theorist and practitioner of Pedagogics and Didactics of the Medieval East.

All Rumi's views serve as a valuable source in the spiritual and moral formation of a person. Because in the teaching methods of Rumi such qualities as human feelings, conscience, purity of the soul and strong will be taken into consideration. Using the teaching methods of Rumi in the process of spiritual and moral development of a person, it is possible to teach the students to think independently, to develop their creative thinking, to make the process of knowledge aquirement active, to find solutions to the problems and to form their skills and expertise.

\section{References}

Navoi, A. (2001). Complete Works in 20 Volumes 1-18. Tashkent, 1987-2002, 17 volume, 460 p.

Radiy, F. (1986). Jalāl-Ad-Dīn Rumi. Translation from Russian J. Kamol, Tashkent, 272 p.

Karimov, I. A. (2011). Yuksak ma’naviyat—engilmas kuch (High Spirituality—An Invincible Force). Tashkent, 176 p.

NATIONAL Instruction of Trained Personnel (1997). Perfect-Generation Development Bases in Uzbekistan. Tashkent, 250 p.

Iste’lomiy, M. (2001). Ilohiy ishq kuychisi (Singer divine passion). (Mavlono Jalāl-addin Muhammad Balkhi). Translation from Farsi J. Muhammad, Tehron, 88 p.

Jalāl-ad-Dīn, R. (2003). Fihi Ma Fihi (In It What’s in It). Translation from Farsi U. Hamdam, Tashkent, 200 p.

Jalāl-ad-Dīn, R. (2010). Maṭnawìye Ma’nawī (Spiritual Couplets). Translation from Farsi J. Kamol, Tashkent, 846 p.

Purnomdoriyon, T. (2001). Mavlaviy sheriyatida “men” dagi “men” lik va matndagi noan’anaviylik (Lyric poetry Mawlawi).

"Sino" Journal, 1, 3. 
Scientific Research Publishing (SCIRP) is one of the largest Open Access journal publishers. It is currently publishing more than 200 open access, online, peer-reviewed journals covering a wide range of academic disciplines. SCIRP serves the worldwide academic communities and contributes to the progress and application of science with its publication.

Other selected journals from SCIRP are listed as below. Submit your manuscript to us via either submit@scirp.org or Online Submission Portal.
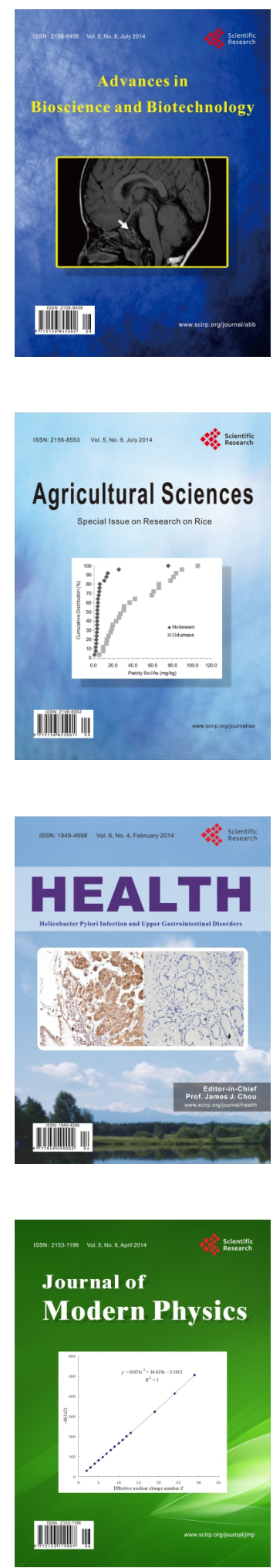
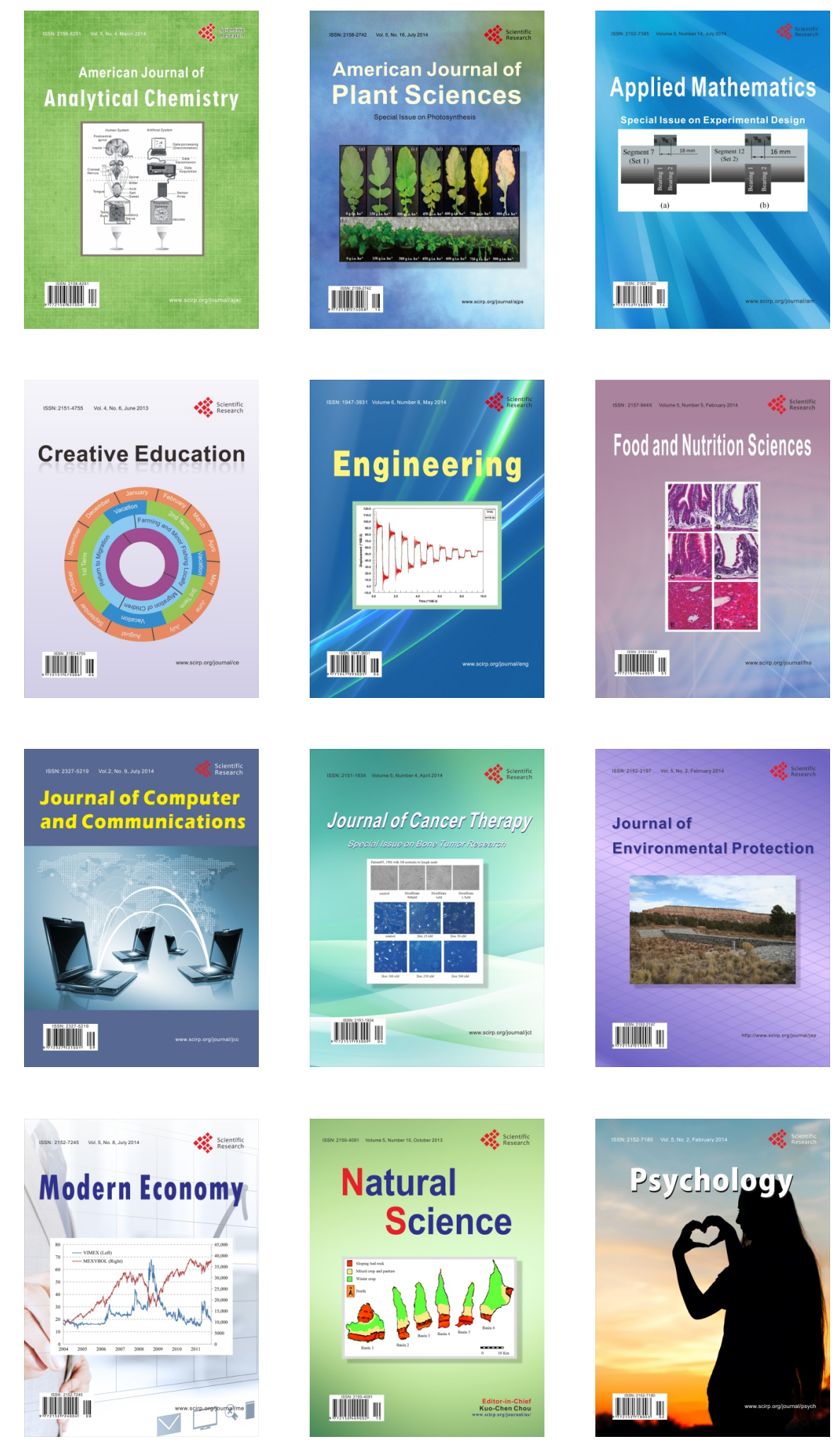